DOI: https://doi.org/10.35387/ucj.2(2).2020.71-78

ЛЮДМИЛА ДЯЧЕНКО

\title{
ПРОФЕСІЙНО-ПЕДАГОГІЧНА ПРАКТИКА МАЙБУТНІХ УЧИТЕЛІВ У ЗАГАЛЬНООСВІТНІХ ШКОЛАХ ФРН
}

\begin{abstract}
Анотація. Розкрито особливості організації професійно-педагогічної практики майбутніх учителів у загальноосвітніх школах Федеративної Республіки Німеччина (ФРН). Виявлено, що у результаті реформаційних перетворень на початку ХХІ cm. у ФРН професійна підготовка майбутніх учителів в університетах набула більшої практичної спрямованості. Охарактеризовано умови реалізації нових видів практики студентів у загальноосвітніх школах ФРН, а саме: практика на профпридатність, практика-орієнтування, практика професійного поля, практичний семестр. 3'ясовано, що практика на профпридатність не є складовою університетської фази підготовки, але $\epsilon$ однією з умов допуску до проходження стажування після завершення навчання в університеті. Встановлено, що обов'язковою умовою для зарахування претендент на посаду вчителя $\epsilon$ стажування - друга фаза підготовки вчителів у ФРН. Виявлено, що під час професійно-педагогічної практики і стажування значна увага приділяється рефлексії індивіду-ального досвіду студентом $i$ стажером, що надає можливості проаналізувати здібності майбут-нього вчителя і визначити перспективи подальшого професійного розвитку. Розкрито значення портфоліо студента, яке містить протокол рефлексії індивідуального досвіду практики, і є роз-горнутим описом професійної біографії майбутнього вчителя. Наявність портфоліо є однією з умов допуску студента до проходження стажування в школі після завершення навчання в уні-верситеті. 3'ясовано, що ефективність підготовки майбутніх учителів залежить не лише від змі-сту освітніх програм, а й від якості педагогічного супроводу осіб, задіяних у здійсненні консу-льтативної підтримки студентівпрактикантів. Обгрунтовано, що прогресивні ідеї німецького досвіду педагогічної освіти є актуальними в умовах освітніх реформ в Україні.
\end{abstract}

Ключові слова: професійно-педагогічна практика, практика на профпридатність, практика-орієнтування, практика педагогічного поля, стажування, портфоліо, загальноосвітня школа, майбутній учитель, Федеративна Республіка Німеччина.

\section{PROFESSIONAL AND PEDAGOGICAL PRACTICE OF FUTURE TEACHERS IN SECONDARY SCHOOLS OF GERMANY}

\begin{abstract}
The organizational peculiarities of professional and pedagogical practice for future teachers in general schools in the Federal Republic of Germany (FRG) are revealed. It was identified that in Germany at the beginning of the XXI century as a result of the reformation, the future teachers' professional training in universities has become more practical. The conditions of new types of students' practice realization in general schools of the FRG are described, namely: practice on professional aptitude, practiceorientation, practice of a professional field, practical semester. It has been found that the practice on professional aptitude is not an integral part of the university phase of training, but is one of the conditions for admission to the internship after the graduation from the university. It has been established that an obligatory condition for enrolling an applicant for a teacher position is an internship - the second phase of teacher training in the FRG. It is revealed that during professional pedagogical practice and internship considerable attention is paid to the reflection of the individual experience of the student and the trainee, which provides an opportunity to analyze the abilities of the future teacher and determine the prospects for further professional development. The value of the student portfolio, which contains the protocol of reflection of the individual experience of practice and is a description of professional biography of the future teacher, is revealed. The portfolio is one of the conditions for admitting a student to undergo an internship at a school after completing university studies. It has been determined that the effectiveness of future teachers training depends not only on the content of educational programs, but also on the quality of pedagogical support of persons involved in the advisory support for students. It is substantiated that progressive ideas of the German experience of pedagogical education are relevant in the context of educational reforms in Ukraine.

Key words: professional and pedagogical practice, practice on professional aptitude, practiceorientation, practice of a professional field, internship, portfolio, general education school, a future teachers, Federal Republic of Germany.
\end{abstract}

Вступ. Динамізм розвитку Європейського Союзу на початку 2000-х років та поява нових підходів до підготовки фахівців зу- мовили переосмислення соціальної ролі й статусу педагогічних працівників, їхніх функцій у суспільстві знань. У міжнародних 
правових актах (документи ЮНЕСКО, Організації економічного співробітництва та розвитку (ОЕСР), Ради Європи та інші) зазначено, що саме потенціал учительського корпусу $є$ основою забезпечення високої якості та конкурентоспроможності освіти на світовому ринку праці, а вчитель XXI століття проголошений носієм суспільних змін. Зокрема у документах ЮНЕСКО («Викладання і навчання: забезпечення якості для всіх» (2014), «Ічхонська декларація: Освіта - 2030» (2015), «Розвиток освітньої політики щодо підготовки і діяльності вчителів» (2015) наголошується на потребі залучення до освітнього процесу в школі відповідальних, ініціативних і компетентних учителів 3 активною професійною i громадянською позицією, здатних до налагодження дієвого партнерства у педагогічній діяльності, розвитку громадянського суспільства, участі у формуванні державної політики у сфері освіти.

На особливому значенні підготовки педагогічних працівників, які $\epsilon$ основною рушійною силою оновлення національної системи освіти, наголошено також у ключових українських документах, таких як: Закон України «Про освіту» (2017), Національна стратегія розвитку освіти в Україні на період до 2021 року (2013), Концепція реалізації державної політики у сфері реформування загальної середньої освіти «Нова українська школа» Кабінету Міністрів України (2017), Розпорядження Кабінету Міністрів України «Про додаткові заходи щодо підвищення кваліфікації педагогічних працівників у 2018 році» (2018), Концепція розвитку педагогічної освіти України (2018).

Зокрема в Національній стратегії розвитку освіти в Україні на період до 2021 року серед стратегічних напрямів розвитку освіти задекларовано необхідність модернізації структури, змісту та організації освіти на засадах компетентнісного підходу, що переносить акценти з процесу накопичення нормативно визначених знань, умінь і навичок в площину формування й розвитку здатності практично діяти і творчо застосовувати набуті знання і досвід у різних ситуаціях. У такій концептуальній схемі професійна педагогічна підготовка майбутнього вчителя повинна бути діяльнісно і особистісно орієнтованою, оскільки компетентності розвиваються і виявляються в діяльності за умови глибокого особистісного зацікавлення, та на основі комплексних міждисциплінарних знань, зорієнтованих на розв'язання проблем практичної діяльності. Це, безумовно, актуалізує потребу оновлення педагогічної практики студентів у загальноосвітніх школах.

У контексті зазначеного, досвід підготовки вчителів загальноосвітніх шкіл у ФРН відкриває нові можливості для удосконалення педагогічної освіти в Україні в умовах її адаптації до вимог загальноєвропейського освітнього простору.

Мета дослідження. Спираючись на доцільність використання ідей зарубіжного досвіду підготовки вчителів в умовах реформаційних змін освітньої галузі України, нами визначена мета статті - охарактеризувати особливості організації професійнопедагогічної практики студентів у загальноосвітніх школах ФРН.

Теоретична основа та методи дослідження. За роки незалежності нашої держави посилився інтерес дослідниківкомпаративістів до вивчення системи освіти ФРН. Різні аспекти німецької моделі підготовки педагогічних кадрів досліджували Н. Абашкіна, В. Кравець, Т. Мойсеєнко, Л. Пуховська та інші. Реформування системи педагогічної освіти в Німеччині проаналізувала Н. Махиня (2009). Практикоорієнтовану спрямованість професійної підготовки вчителів у цій країні проаналізував С. Бобраков (2014).

Важливими для нашого дослідження стали наукові доробки таких німецьких вчених: Х. Брінкман (H. Brinkmann), Й. Майер (J. Mayr), Е. Стіллер (Е. Stiller), Ф. Фільмер (F. Filmer), які у своїх працях розкрили особливості професійно-педагогічної практики студентів у загальноосвітніх школах ФРН.

Для досягнення мети дослідження було застосовано такі методи: загальнонаукові (аналіз, синтез, узагальнення), на основі яких виявлено стан професійної педагогічної підготовки учителів загальноосвітніх шкіл у ФРН на початку XXI століття; хронологічного аналізу, який дав змогу розглянути реформаційні перетворення педагогічної освіти ФРН на початку XXI ст.; аналізу документів, що сприяв вивченню нормативно-правової бази забезпечення професій- 
ної підготовки учителів; критичнооб'єктивного аналізу, що став основою з'ясування особливостей професійнопедагогічної практики майбутніх учителів у загальноосвітніх школах ФРН; порівняльно-педагогічного аналізу, що допоміг виявити проблемні питання професійної підготовки майбутніх учителів в Україні; методи екстраполяції та прогностики, що сприяли визначенню перспектив використання прогресивних ідей німецького досвіду професійно-педагогічної практики майбутніх учителів у системі вищої педагогічної освіти України.

Виклад основного матеріалу. Провідним компонентом реформованої системи педагогічної освіти у ФРН є практична підготовки майбутніх учителів загальноосвітніх шкіл до професійної педагогічної діяльності. Введення нових елементів практики під час навчання в університеті було зафіксовано у земельних законах про підготовку учителів. Серед нових видів практичних компонентів університетської підготовки майбутніх учителів було виділено такі: практика на профпридатність (Eignungspraktikum), практика-орієнтування (Orientierungspraktikum), практика професійного поля (Berufsfeldpraktikum), практичний семестр (Praxissemester) (Geset züber die Aus-, 2014).

Результати проходження усіх видів практики фіксуються у педагогічному портфоліо, оформлення якого $\epsilon$ обов'язковим для зарахування практики та однією з умов допуску до подальшого стажування в школі протягом 18-ти місяців після завершення навчання в університеті. Після стажування претендент на посаду вчителя складає другий державний екзамен, після якого молодий педагог матиме повне право працювати вчителем у школі відповідного типу.

Підвищення якості підготовки майбутніх учителів завдяки введенню нових практичних компонентів до університетської підготовки та оновлення стажування відзначають представники земельних Мiністерств освіти Німеччини Х. Брінкман (Brinkmann, 2013), С. Льорман (Löhrmann, 2013), Е. Стіллер (Stiller, 2011), Ф. Фільмер (Filmer, 2013) і професори німецьких університетів А. Грьошнер (Gröschner, 2014),
Й. Майр (Mayr, 2006), Б. Ніскенс (Nieskens, 2013) та інші.

Німецькі науковці підкреслюють, що одним з результативних кроків у напрямі розвитку професійної відповідальності в педагогічній галузі $є$ запровадження практики на профпридатність, оскільки, вступаючи до закладу вищої освіти, молода людина не завжди повністю усвідомлює правильність свого вибору.

Практику на профпридатність проходять абітурієнти, які у майбутньому прагнуть стати вчителями. Ї̈̈ тривалість становить 20 днів у школі. Головною метою цього виду практики $\epsilon$ рефлексія власного професійного вибору. Основними завданнями практики на профпридатність є такі: 1) рефлексія власного досвіду навчання 3 позиції вчителя; 2) створення уявлення про школу як про місце роботи; 3) аналіз власних здібностей і можливостей, їх співвіднесення з вимогами обраного виду професійної діяльності; 4) виокремлення проблемних пунктів своєї підготовки до професії; 5) з'ясування здатності виконувати цю роботу у майбутньому; 6) усвідомлення правильності або хибності вибору професії (Bundesrepublik Deutschland. Ministerium für Schule und Weiterbildung des Landes Nordrhein-Westfalen, 2009, c. 330).

Успішність практики на профпридатність визначається за стандартами, затвердженими земельним Міністерством освіти, а саме: 1) випускник практики здатен сприймати і аналізувати ситуацію навчання кожного учня як індивідуальне учіння; 2) здатен брати на себе роль учителя i аналізувати свою поведінку; 3) сприймає школу як єдину організацію i місце роботи, як поле власної практичної діяльності; 4) апробує і аналізує свої можливості у професійній педагогічній діяльності, оцінює вибір професії на основі здобутого досвіду (Bundesrepublik Deutschland. Ministerium für Schule und Weiterbildung des Landes Nordrhein-Westfalen, 2009, c. 331).

Протокол рефлексії практики передбачає опис ситуацій, що сприяли набуттю відповідних здібностей і визначення власних можливостей за кожним із стандартів (Bundesrepublik Deutschland. Ministerium für Schule und Weiterbildung des Landes Nordrhein-Westfalen, 2010). 
Ключовим значенням практики на профпридатність є, на нашу думку, можливість набути першого практичного професійного досвіту: ознайомитись з діяльністю вчителя, не з позиції учня - сидячи за партою, а випробувати себе у якості майбутнього фахівця ще до початку навчання.

Перейдемо до огляду практичних компонентів університетської підготовки. Під час навчання в університетах студенти на шляху до професії вчителя проходять професійно-педагогічну практику, яка складається 3 двох блоків, а саме: 1) для майбутніх бакалаврів - практика-орієнтування (1 місяць) і практика професійного поля (1 місяць); 2) для майбутніх магістрів практичний семестр (5 місяців) (Gesetz über die Ausbildung, 2009; Modulhandbuch Bachelor of Arts, 2015; Modulhandbuch Master of Education, 2015).

За організацію і проходження студентами першого блоку практики відповідають центри підготовки вчителів при університетах. Головними завданнями центрів $\epsilon$ забезпечення науково-методичного супроводу практичної підготовки, підтримка взаємозв'язків зі школами, підготовка учителів-наставників, які здійснюватимуть супровід студентів-майбутніх бакалаврів під час практики-орієнтуванні та практики професійного поля.

Перший блок практики має три організаційні етапи:

1) підготовчий, на якому студент визначається 3 місцем проходження практики, оформлює супровідні документи і бере участь у підготовчому семінарі в університеті;

2) практичний, під час якого студент здобуває досвід педагогічної діяльності в школі (практика-орієнтування) або у закладах позашкільної освіти (це можливо під час практики професійного поля) та відвідує семінар-супровід в університеті;

3) заключний, що передбачає оформлення портфоліо, проведення заключних бесід студента 3 учителем-наставником, адміністрацією школи, викладачем університету, учнями та подальше оцінювання (Walke, 2012, с. 5).

Серед цілей практики-орієнтування виявлено такі: 1) оцінити свої знання з огляду достатності чи недостатності для забезпечення реалізації навчального процесу в школі; 2) розвивати дослідницьку спрямованість навчання в університеті з метою поглиблення власних знань і здібностей; 3) сформувати здатність до самоорганізації і тайм-менеджменту; 4) розвивати комунікативну компетентність, оскільки комунікація та інтеракція є основою налагодження стосунків між людьми (Modulhandbuch Bachelor of Arts, 2015, с. 4).

Успішність практики-орієнтування визначається за чотирма стандартами, затвердженими земельним Міністерством освіти, серед яких виділено такі: 1) випускник практики-орієнтування здатен комплексно і системно вивчати особливості професійної педагогічної діяльності; 2) здатен встановлювати взаємозв'язки між теоретичними знаннями за блоком «Науки про освіту» і конкретними педагогічними ситуаціями; 3) здатен створювати власні ситуації професійної педагогічної діяльності; 4) здатен самостійно здійснювати рефлексію власного досвіду педагогічної діяльності та професійного розвитку (Bundesrepublik Deutschland. Ministerium für Schule und Weiterbildung des Landes Nordrhein-Westfalen, 2009, с. 341).

Наступною складовою блоку професійно-педагогічної практики для майбутніх учителів освітнього ступеню бакалавра $€$ практика професійного поля. Основними цілями практики професійного поля є такі: 1) поглиблення досвіду, отриманого студентами під час практики-орієнтування; 2) розширення уявлень про сферу професійної педагогічної діяльності; 3) проекція теоретичних знань за блоком «Науки про освіту» на сферу позашкільної освіти; 4) визначення конкретних професійних перспектив роботи в школі чи альтернатив педагогічної діяльності поза нею (Stiller, 2011, с. 6).

Відповідно до означених цілей майбутні учителі можуть проходити практику як безпосередньо в школі, так і у закладах позашкільної освіти. Осередками для проходження практики професійного поля можуть бути такі позашкільні установи: громадські молодіжні центри, церковні центри соціальної підтримки, центри служби зайнятості, консультативні центри для молоді при земельному Міністерстві освіти, асоціації вальфдорської педагогіки, центри 
реабілітації дітей та молоді (для вчителів спеціальних шкіл), культурно-мистецькі центри (для вчителів музики і образотворчого мистецтва), освітні центри на базі виробничих підприємств (для вчителів професійних шкіл) тощо (Walke, 2012, с. 11).

Практика професійного поля може відбуватися в школі, але у цьому випадку матиме іншу спрямованість, порівняно зі змістом практики-орієнтування, зокрема вона може здійснюватись за такими напрямами: підготовка і реалізація навчальнодослідного проекту, реалізація соціальної роботи в школі, здійснення психологопедагогічного консультування, проведення розвивальних соціально-психологічних тренінгів, організація дозвілля, реалізація завдань психолого-педагогічного супроводу, адміністративна робота у школі тощо (Walke, 2012, с. 11).

Успішність практики професійного поля визначається за такими ж чотирма стандартами, як і практика-орієнтування, оскільки ці два види практики є компонентами блоку практичної підготовки майбутніх учителів освітнього ступеню бакалавра (Bundesrepublik Deutschland. Ministerium für Schule und Weiterbildung des Landes Nordrhein-Westfalen, 2009, с. 341).

Другий блок практики - це практичний семестр, який компонентом університетської підготовки майбутніх учителів освітнього ступеню магістра. Тривалість практичного семестру п'ять місяців, протягом яких студент набуває досвіду підготовки та реалізації навчально-дослідних проектів, досвіду планування, проведення та аналізу уроків, психолого-педагогічного супроводу учнів. Цілями практичного семестру є такі: 1) забезпечення нерозривного зв'язку професійно орієнтованої теорії і практики; 2) здійснення професійно-педагогічної підготовки студентів до виконання вимог школи; 3) забезпечення готовності випускників університетів до стажування в школі (Bundesrepublik Deutschland. Ministerium für Schule und Weiterbildung des Landes Nordrhein-Westfalen, 2010a, c. 2).

Спільна відповідальність за проходження практики студентами покладена на такі установи: університет, центр шкільної практичної підготовки, що підпорядковується земельному Міністерству освіти, і школа, де студент буде проходити практику.

Практичний семестр в школі закінчується спільним підведенням підсумків студента-практиканта, вчителя-наставника i консультанта центру шкільної практичної підготовки. Співбесіда не $\epsilon$ екзаменом і не оцінюється, а проходить у вигляді зворотного зв'язку, щоб студент зміг критично оцінити результати практики, визначити свої переваги і напрями професійного розвитку, на які особливо треба звернути увагу для підвищення ефективності педагогічної діяльності школі (Bundesrepublik Deutschland. Ministerium für Schule und Weiterbildung des Landes Nordrhein-Westfalen, 2010a, c. 16).

Основними критеріями успішності практичного семестру є такі: 1) випускник практичного семестру здатен здійснювати планування, проведення і аналіз основних елементів шкільного навчання і научіння на основі наукових знань 3 предмету викладання і його дидактики, наукових знань блоку «Науки про освіту»; 2) здатен застосовувати і аналізувати концепції і методи оцінювання успішності, педагогічної діагностики та індивідуального супроводу; 3) сприймати та виконувати виховні завдання школи; 4) планувати науковообгрунтовані дослідження професійного поля школи, проводити і аналізувати їх у взаємозв'язку науки і практики; 5) розвивати власну професійну Я - концепцію (школі (Bundesrepublik Deutschland. Ministerium für Schule und Weiterbildung des Landes Nordrhein-Westfalen, 2010a, c. 4; Bundesrepublik Deutschland. Ministerium für Schule und Weiterbildung des Landes NordrheinWestfalen, 2009, c. 332).

Після успішного складання першого державного екзамену, одним з компонентів якого $є$ оцінювання портфоліо з описом досвіду проходження усіх практичних компонентів, студент отримує диплом освітнього ступеню «Магістр». Водночас диплом не надає права повноцінного самостійного викладання в школі - претендент на посаду вчителя зобов'язаний пройти стажуван- 
ня в школі протягом 18-ти місяців. Супровід стажування здійснює консультант центру шкільної практичної підготовки та вчитель-наставник школи, куди за земельним розподілом направляється стажер (Bundesrepublik Deutschland. Ministerium für Schule und Weiterbildung des Landes Nordrhein-Westfalen, 2013).

Зазначимо, що однією з умов стажування $€$ оформлення портфоліо, що включає такі обов'язкові компоненти:

1) анкету для спільного обговорення перспектив подальшого професійного розвитку вчителя;

2) протокол рефлексії індивідуального досвіду відповідно до вищезгаданих шести полів діяльності;

3) лист-узагальнення результатів стажування також за шістьма полями діяльності (Bundesrepublik Deutschland. Ministerium für Schule und Weiterbildung des Landes Nordrhein-Westfalen, 2013a, c. 2).

Особливості організації стажування як другої фаза підготовки вчителів у ФРН розкриємо у наступному випуску цього видання.

Висновки. Проаналізувавши особливості організації професійно-педагогічної практики майбутніх учителів загальноосвітніх шкіл у ФРН, можемо зробити ряд висновків:

-у результаті реформ на початку XXI століття у ФРН підготовка майбутніх учителів в університеті набула більшої практичної спрямованості завдяки введенню компонентів практичної підготовки, а саме: практики на профпридатність, практики-орієнтування, практики професійного поля, практичного семестру;

- підготовка студентів до практики в школі здійснюється у формі семінарів і тренінгів для відпрацювання поведінкового репертуару майбутнього вчителя, розвитку його соціально-комунікативної компетентності;

- змін, як структурних, так і змістовних, зазнала також друга фаза підготовки вчи- телів - стажування, під час якого домінуючою $\epsilon$ практична орієнтація підготовки вчителя-стажера;

- під час професійно-педагогічної практики значна увага приділяється рефлексії індивідуального досвіду студентівпрактикантів, що надає можливості проаналізувати здібності майбутніх учителів і визначити перспективи подальшого професійного розвитку;

- завдяки введенню компонентів практичної підготовки під час навчання в університеті відбулося зміцнення зв'язків між вищим навчальним закладом, центром практичної підготовки учителів і школою;

- оскільки ефективність підготовки майбутніх учителів залежить не лише від змісту освітніх програм, а й від якості педагогічного супроводу під час практики, передбачено розширення кількості заходів 3 підвищення кваліфікації осіб, задіяних у здійсненні консультативної підтримки студентів-практикантів.

Прогресивні ідеї німецького досвіду педагогічної освіти $є$ актуальними і перспективними для вирішення проблемних питань професійної підготовки майбутніх учителів в Україні, таких як: низький рівень зв'язку закладів вищої освіти із загальноосвітніми школами, що унеможливлює урахування у підготовці майбутнього вчителя реалій школи; нераціональне співвідношення теоретичного і практичного компонентів у процесі розвитку професійної компетентності; невідповідність теоретичних знань 3 фахових дисциплін наявним потребами їх застосування на практиці; неспроможність школи прийняти й організувати на належному рівні практичну підготовку студентів; брак спеціальної підготовки учителів, які здійснюють педагогічний супровід студентів-практикантів; домінування пасивної позиції студентапрактиканта як спостерігача, замість безпосередньої участі у житті школи, підготовці і проведенні уроків, позакласних заходів.

\section{ЛІТЕРАТУРА}

Бобраков, С. В. (2014). Практико-орієнтована спрямованість професійної підготовки вчителів у вищих навчальних закладах Німеччини. (Автореф. дис. канд. пед. наук). Державний заклад «Луганський національний університет імені Тараса Шевченка», Луганськ. (Bobrakov, S. V. 
(2014). Praktyko-orientovana spriamovanist profesiinoi pidgotovky vchyteliv u vyshcyh navchalnyh zakladah Nimecchyny. (Avtoref. dys. kand. ped. nauk). Derzhavnyi zaklad «Luhanskyi nationalnyi universytet imeni Tarasa Shevchenka», Luhansk.)

Махиня, Н. В. (2009). Реформування системи педагогічної освіти Німеччини (друга половина ХХ початок XXI cm.). (Автореф. дис. канд. пед. наук). Кіровоградський державний педагогічний університет імені В. Винниченка, Кіровоград. (Маhynia, N. V. (2009). Reformuvannia systemy pedagogichnoi osvity Nimecchyny. (Avtoref. dys. kand. ped. nauk). Kirovogradskyi derzhavnyi pedagogichnyi universytet imeni V.Vynnychenka, Kirovohrad.)

Brinkmann, H. (2013). Die neue Staatsprüfung. Der reformierte Vorbereitungsdienst. Schule NRW : Amtsblatt des Ministeriums für Schule und Weiterbildung des Landes Nordrhein-Westfalen, Januar (1), 2022.

Bundesrepublik Deutschland. Ministerium für Schule und Weiterbildung des Landes Nordrhein-Westfalen. (2009). Verordnung über den Zugang zum nordrhein-westfälischen Vorbereitungsdienst für Lehrämter an Schulen und Voraussetzungen bundesweiter Mobilität (Lehramtszugangsverordnung LZV) vom 18. Juni 2009. Gesetz- und Verordnungsblatt für das Land Nordrhein-Westfalen, 16, 327348.

Bundesrepublik Deutschland. Ministerium für Schule und Weiterbildung des Landes Nordrhein-Westfalen. (2010). Das Eignungspraktikum Das erste Praxiselement der Lehrerausbildung nach dem Lehrerausbildungsgesetz vom 12. Mai 2009: Informationen für Lehrerinnen und Lehrer der Zukunf vom 14. Juli 2010. Düsseldorf: Ministerium für Schule und Weiterbildung des Landes Nordrhein-Westfalen.

Bundesrepublik Deutschland. Ministerium für Schule und Weiterbildung des Landes Nordrhein-Westfalen. (2010a). Rahmenkonzeption zur strukturellen und inhaltlichen Ausgestaltung des Praxissemesters im lehramtsbezogenen Masterstudiengang. Köln: Ministerium für Schule und Weiterbildung des Landes Nordrhein-Westfalen.

Bundesrepublik Deutschland. Ministerium für Schule und Weiterbildung des Landes Nordrhein-Westfalen. (2012). Kerncurriculum für die Ausbildung im Vorbereitungsdienst für Lehrämter in den Zentren für schulpraktische Lehrerausbildung und in den Ausbildungsschulen. Schule NRW: Amtsblatt des Ministeriums für Schule und Weiterbildung des Landes Nordrhein-Westfalen. Januar (1). Düsseldorf: Ministerium für Schule und Weiterbildung.

Bundesrepublik Deutschland. Ministerium für Schule und Weiterbildung des Landes Nordrhein-Westfalen. (2013). Ordnung des Vorbereitungsdienstes und der Staatsprüfung für Lehrämter an Schulen vom 10. April 2011. Schule NRW: Amtsblatt des Ministeriums für Schule und Weiterbildung des Landes Nordrhein-Westfalen, Januar (1), 64-71.

Bundesrepublik Deutschland. Ministerium für Schule und Weiterbildung des Landes Nordrhein-Westfalen. (2013a). Portfolio-Einlagen für den Vorbereitungsdienst : Erprobungsfassung. Beilage Schule NRW : Amtsblatt des Ministeriums für Schule und Weiterbildung des Landes Nordrhein-Westfalen. September (9). Düsseldorf : Ministerium für Schule und Weiterbildung.

Filmer, F. (2013). Akkreditierungals Qualitätssicherung. Schule NRW: Amtsblatt des Ministeriums für Schule und Weiterbildung des Landes Nordrhein-Westfalen, Januar (1), 32-34.

Geset züber die Aus-, Fort- und Weiterbildung der Lehrerinnen und Lehrer im Land Berlin (Lehrkräftebildungsgesetz - LBiG) vom 7. Februar 2014. (2014). Gesetz- und Verordnungsblatt für Berlin, 4, 4954.

Gesetz über die Ausbildung für Lehrämter an öffentlichen Schulen (Lehrerausbildungsgesetz) vom 12. Mai 2009. (2009). Gesetz- und Verordnungsblatt für das Land Nordrhein-Westfalen, 14, 308-313.

Gröschner, A. (2014). Praxisphasen im Lehramtsstudium: Ausgewählte Befunde zu Wirksamkeit und Gelingensbedingungen. Fokus Praxissemester. In S. Barsch, M. Dziak-Mahler (Hrsg.), Das Kölner Modell kritisch beleuchtet: Werkstattberichte (s. 41-49). Köln: Zentrum für LehrerInnenbildung (ZfL); Universität zu Köln.

Löhrmann, S. (2013). Weichen für die Zukunft gestellt. Schule NRW : Amtsblatt des Ministeriums für Schule und Weiterbildung des Landes Nordrhein-Westfalen, Januar (1), 2.

Mayr, J. (2006). Teorie + Übung + Praxis = Kompetenzen? Empirische begründete Rückfrage zu den Standards in der Lehrerbildung. Zeitschrift für Pädagogik, 51(2), 149-163.

Modulhandbuch Bachelor of Arts. Bildungswissenschaften. Studiengang Lehramt an Gymnasien und Gesamtschulen. (2015). Köln: Humanwissenschaftliche Fakultät, Universität zu Köln. URL: https://www.hf.uni-koeln.de/data/hflehrestudium/File/Modulhandbuecher/UzK HF_MHB GYMGE_BA BIWI 150901_Entwurf.pdf 
Modulhandbuch Master of Education. Bildungswissenschaften. Studiengang Lehramt an Gymnasien und Gesamtschulen. (2015). Köln: Humanwissenschaftliche Fakultät, Universität zu Köln. URL: http://www.hf.uni-koeln.de/data/hflehrestudium/File/Modulhandbuecher/UzK HF_MHB_GyGe_MEd_BiWi_150901.pdf.

Nieskens, B. (2013) Seiteneinstieg: Neue Lehrkräfte bei der Eignungsabklärung unterstützen. Schule NRW: Amtsblatt des Ministeriums für Schule und Weiterbildung des Landes Nordrhein-Westfalen, Januar (1), 29-31.

Stiller, E. (2011). Arbeitsstand der gemischten Arbeitsgruppe Portfolio Praxiselemente von 30. Juni 2010. In Stiller E. (Leitung), Chancen portfolio gestützter Reflexionsarbeit: Tagungsreader (s. 8-25). Düsseldorf, Köln: Ministerium für Schule und Weiterbildung des Landes Nordrhein-Westfalen; Universität zu Köln.

Stiller, E. (2013). Das neue Praxissemester. Schule NRW: Amtsblatt des Ministeriums für Schule und Weiterbildung des Landes Nordrhein-Westfalen, Januar (1), 26-28.

Walke, J. (2012). Bachelor: Orientierungspraktikum und Berufsfeldpraktikum: Informationen zu den Praxisphasen des Lehramtsstudiums ab WS 2011 - 2012. Münster: Zentrum für Lehrerbildung der Universität Münster.

Людмила Дяченко, кандидат педагогічних наук, старший науковий співробітник відділу зарубіжних систем педагогічної освіти і освіти дорослих Інституту педагогічної освіти і освіти дорослих імені Івана Зязюна НАПН України.

Liudmyla Diachenko, PhD in Pedagogy, Senior Research Staff of Department of Foreign Pedagogical and Adult Education Systems at Ivan Ziaziun Institute of Pedagogical and Adult Education of NAES of Ukraine.

E-mail: diachenko.Im@gmail.com ORCID ID 0000-0001-6897-124X

Received: 18.10.2020

Accepted: 21.11.2020 